\section{PAPER LENGTH IN THE BRITISH JOURNAL OF PSYCHIATRY AND PSYCHOLOGICAL MEDICINE}

\section{DeAR Sir,}

The British Journal of Psychiatry publishes fewer long papers and more short papers than Psychological Medicine. Could authors have public guidance whether this is editorial policy?
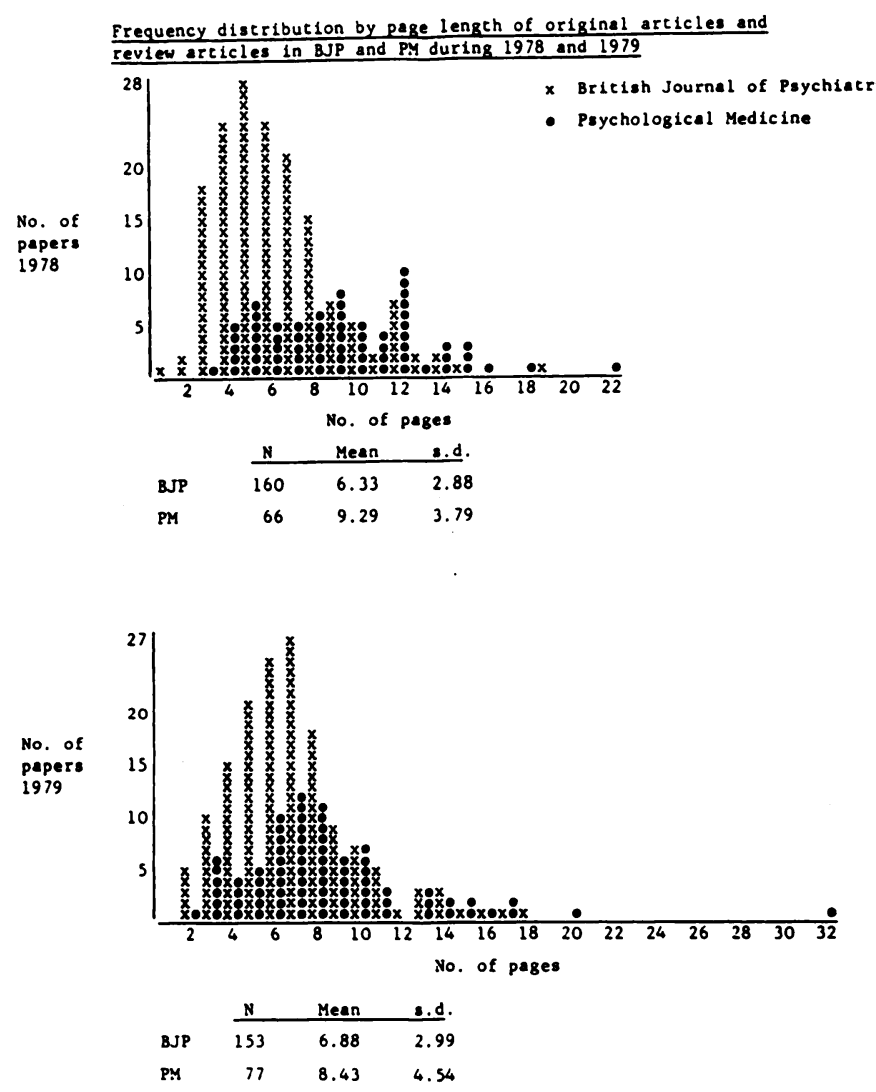

Royal South Hants Hospital,

Graham Road,

Southampton SO9 4PE

The present policy of this Journal is to have no policy about length as such, but to expect length to be related to the importance, interest, and novelty of the subject matter addressed to psychiatric readers. In papers reporting original studies we look with disfavour on long reviews of the literature if these are available elsewhere, except in special cases; also on long discursive and speculative discussions of rather few data: each subject has its appropriate length. Some of the papers we publish are shorter than the manuscripts originally submitted. Even so, every rule has its exceptions.-Editor.

\section{AN EARLY CASE OF BATTLE HYSTERIA}

\section{DeAR SiR,}

Hysterical symptoms in the field of battle were first recognized during the First World War, and have been the subject of a number of monographs e.g. Hurst (1940), Yealland (1918), and Mott (1919). It is likely that many cases occurred in previous wars, but remained unrecognized owing to the limitations of medical knowledge. I would like to report a case of hysterical blindness that occurred during the Peninsular War (1808-14).

My great-grandfather, on his retirement, wrote a history of his own life and that of his family as it had been told to him. The history has been continued by each successive generation, but has not been published. The history starts with an account of my greatgreat-great-grandfather, who had been a weaver in Ayrshire before enlisting in the 94th Regiment. He was soon in active service. During the Peninsular War he fought in nine engagements and had many narrow escapes. It was towards the end of the campaign he became blind:

"He had been assisting the surgeons and rubbed his eyes, while his hands were bloody and got poison into them and became blind. He was invalided home or rather to Kilmainham Hospital in Ireland, where they did all they could to cure his blindness, but without effect so he missed being at Waterloo.

His father hearing of him being at Kilmainham, and that all hopes of his getting his sight had been given up, he petitioned the War Office for his discharge which was granted. His father with 2 or 3 friends to help, set sail in a small boat from Ayr and got my grandfather on board and set sail for home. On a part of the journey it became necessary to lower the sail, and he took more of the rowing.

Whether it was the exercise or whether the disease had worked itself out, they did not know, but the blind man whispered to his father that he could see the man in the boat. His father thought it best that the fact should not be known. After the long war there was a great demand for men and I suppose his father would be afraid that if it was known that his sight had returned he would be sent back to his Regiment so he kept about the house and took what exercise he needed in the garden at the back of his father's house.

He renewed his acquaintance with Jean B., whose garden adjoined that of his father's. For a whole month he kept up the impression that he was blind. 
It became impossible, so by and by Jean and he were married".

The sudden onset of blindness in the war and his recovery on the passage home are suggestive of combat hysteria. It is likely that the symptom of blindness was an unconscious attempt to 'shut out' the sights of mutilation he had seen while assisting the Army Surgeon.

Department of Medicine, University Hospital of Wales, Cardiff CF4 $4 X W$

\section{References}

Hurst, A. F. (1940) Medical Diseases of War. London: Edward Arnold.

Mort, F. W. (1919) War Neuroses and Shell Shock. London: Oxford Medical Publications.

YeAlland, L. R. (1918) Hysterical Disorders of Warfare. London: Macmillan.

DeAR SiR,

\section{ANTICIPATORY GRIEF}

Fulton and Gottesman's (Journal, July 1980, 137, 45-54) detailed analysis of the literature on Anticipatory Grief rightly raises doubts about the usefulness of this concept. Unfortunately they have failed to spot a very interesting and important finding which emerges from the large amount of research which they report.

- Despite all the differences in definition and methodology there are three studies which come up with clear evidence of a relationship between forewarning of bereavement and good outcome. The factor which distinguishes these three from the five other quantitative studies is young age. Natterson and Knudson's (1960) study of dying children and Glick's (1974) study of widows and widowers under age 45 both show that in the young age group, the opportunity to anticipate bereavement does reduce the intensity of subsequent distress. Ball's (1977) study allows direct comparison of widows over and under 45 years of age and confirms this finding.

Although Maddison and Walker's (1967) study is referred to by Fulton as being concerned with "young and middle aged" widows in fact widows under 45 were not included in their research.

One other study which was not included by Fulton is a comparison of relatives of 32 patients who had died in Sweden within a few hours of becoming ill and 55 controls most of whom had died from cancer (Lundin, 1979). Both groups were under the age of 65 and the change in morbidity was measured in days of sick-listing from Swedish social insurance claims during 2 years before and after the death. Lundin found that the mean number of days sick increased from 41.2 to 54.0 in the unexpectedly bereaved group and that this was most marked in relatives of patients who had died in a violent accident $(P<.01)$. No such increase was found in the control group although both before and after bereavement morbidity was higher than in the normal population (suggesting that relatives of patients with cancer may suffer stresseffects before as well as after bereavement).

It seems reasonable to conclude that deaths which are both unexpected and untimely are potentially pathogenic.

\section{The London Hospital Medical College \\ Turner Street, London E1 2AD}

\section{References}

BALL, J. F. (1977) Widow's grief: the impact of age and mode of death. Omega, 7, 307-33.

Glick, I. O., Weiss, R. S. \& Parkes, C. M. (1974) The First Year of Bereavement. New York: John Wiley.

Lundin, T. (1979) On Crisis Theory, Reactions to Sudden and Unexpected Death. Proceedings of 10th International Conference for Suicide Prevention and Crisis Intervention. Ottawa, Canada.

MADDISON \& WALKER, W. L. (1967) Factors affecting the outcome of conjugal bereavement. British Journal of Psychiatry, 113, 1057-67.

Natterson, J. M. \& Knudson, A. G. JR. (1960) Observations concerning fear of death in fatally ill children and their mothers. Psychosomatic Medicine, 22, 465.

\section{VULNERABILITY FACTORS AND DEPRESSION}

\section{DEAR SiR,}

Roy (Journal, August 1978, 133, 106 and January $1981,138,75)$ purports to corroborate Brown et al's (1975, 1977) findings that unemployment, lack of a confiding relationship and early parental loss act as vulnerability factors in relation to depression. This conclusion, would not appear to follow from his data.

The features that constitute the essential defining characteristics of vulnerability factors have been hotly disputed (Tennant and Bebbington, 1978; Brown and Harris, 1978, 1980; Bebbington, 1980; Surtees, 1980). Nevertheless, a fundamental point of agreement is that their effects can only be demonstrated in conjunction with information pertaining to life events. Roy (1978) appears to concur with this view in that he defines vulnerability factors as "factors which increase the chances of developing a psychiatric disorder in the presence of an event or difficulty" (p 106).

Despite this definition, however, he failed to collect any information pertaining to the occurrence of life events or difficulties. Thus, in the absence of this information it is not possible to determine whether 